\title{
The Effect of Webfolios on Saudi EFL Students' Self-Directed Learning Readiness
}

\author{
Samah Zakareya ${ }^{1} \&$ Fawziah Al-Qahtani ${ }^{1}$ \\ ${ }^{1}$ College of Sciences and Humanities-Jubail, Imam Abdulrahman Bin Faisal University, Kingdom of Saudi Arabia \\ Correspondence: Samah Zakareya, Jubail College of Sciences and Humanities, Imam Abdulrahman Bin Faisal \\ University, Kingdom of Saudi Arabia.
}

Received: January 28, 2020

Accepted: March 5, $2020 \quad$ Online Published: April 27, 2020

doi:10.5539/ies.v13n5p150

URL: https://doi.org/10.5539/ies.v13n5p150

\begin{abstract}
Webfolios, or web portfolios, are innovative learning tools. Therefore, the objective of this study was to examine the effect of using webfolios on Saudi EFL students' self-directed learning readiness. Participants were pretested on self-directed learning readiness before starting to work on their webfolios. They used Blackboard to create and use their webfolios. After the webfolios were completed, participants were posttested. A significant effect was found for webfolios on participants' self-directed learning readiness. Consequently, it was concluded that webfolios should be used at college level to enhance students' self-directed learning readiness. Some recommendations and suggestions for future research were introduced.
\end{abstract}

Keywords: webfolios, self-directed learning readiness, Saudi EFL students

\section{Introduction}

\subsection{Background to the Problem}

Since we live in the Knowledge Age where there are endless change and extreme diversity and individuals must have the ability to create, use, and share knowledge, human beings need to continually acquire 21 st century skills. One of such skills is self-directed learning (SDL), which enables individuals to successfully fulfill the requirements of constantly changing professions (Saxena, 2013).

A well advocated pedagogical concept is that a person learns better when the flow of experience is under his/her control (i.e., self-directed) (Gureckis \& Markant, 2012). Therefore, SDL has become one of the most-investigated domains of education for the past 4 decades (Guglielmino, 2013). SDL refers to a group of skills including: diagnosing one's learning needs, generating one's own learning goals, identifying one's learning problems, planning to solve these problems, identifying resources, selecting and applying strategies, evaluating the outcomes of learning, and re-planning according to this evaluation (Cheng, Kuo, Lin, \& Lee-Hsieh, 2010; Loyens, Magda, \& Rikers, 2008; Robertson, 2011). To become self-directed learners, students need to develop their ability to identify the demands of the task, assess their own knowledge and skills, develop their plan, check their progress, improve their strategies, and adjust their approaches to learning (Ambrose, Bridges, DiPietro, Lovett \& Norman, 2010). Moreover, SDL refers to the degree to which learners have the abilities, attitudes, and personality characteristics required for SDL (Fisher \& King, 2010).

SDL has many advantages including: allowing learners to learn on their own time and at their own pace (Silva, 2009), improving their ability to learn in new situations (Bastable, 2008), enhancing their ability to be proactive in their learning (Merriam, Caffarella, \& Baumgartner, 2007), and allowing them to concentrate on the useful information (Gureckis \& Markant, 2012) and the transferable skills that will enable them to learn successfully in the future (Robertson, 2011). Moreover, SDL can increase students' trust, independence, motivation and preparedness for ongoing learning (O'Shea, 2003), allow them to take responsibility for managing their learning (Robertson, 2011), and help them become effective learners and social beings (Abdullah, 2001). Therefore, there is increasing recognition of the importance of SDL within higher education (Robertson, 2011). However, despite the benefits of SDL, and despite the fact that self-directed lifelong learning is now found within the mission statements of most higher education institutions (Payne, Rundquist, Harper, \& Gahimer, 2013), learners in different contexts tend to lack SDL skills (Beckers, Dolmans, Knapen, \& Merriënboer, 2018) and students in formal higher education settings are rarely given the opportunity to practice self-directed (Francom, 2011; Hiemstra, 2013). 
The Kingdom of Saudi Arabia, through the 2030 Vision and the 2020 National Transformation Program, intends to eliminate the gap between higher education outcomes and job market. Also contained in the Saudi Vision 2030 is to help students take aware career decisions, while simultaneously facilitating their transition between different educational paths (Government of Saudi Arabia, 2016). Therefore, current trends in higher education in Saudi Arabia emphasize that university students need to develop skills that will enable them to become self-directed learners (El-Gilany \& Abusaad, 2013). Working at Jubail College of Sciences and Humanities, Imam Abdulrahman Bin Faisal University, the researchers noticed that most higher education instructors still rely on teacher-directed approaches rather than SDL. Moreover, she administered an SDL readiness scale to a sample of EFL students and found that most students suffer problems with SDL readiness.

The widespread use of Internet technologies in higher education (Chen, Lambert, \& Guidry, 2010) has compelled teachers to face the challenge of dealing with today's learners, usually called digital natives, who depend on technological communications to get knowledge and to create social and professional relationships (Easton \& Easton, 2011). Therefore, many instructional tools are available for web-based learning instructors (Cook, Garside, Levinson, Dupras, \& Montori, 2010). One of these tools is webfolios (Kennedy, Judd, Churchward, Gray, \& Krause, 2008; Williams \& Walker, 2018). Accordingly, the objective of the present study is to study how webfolios can improve Saudi EFL students' SDL. To achieve this objective, the hypothesis put for the study stated that a statistically significant difference (at 0.05 level of significance) would exist in participants' SDL readiness scores between the pretest and posttest in favor of the posttest.

\subsection{Review of Related Literature}

Generally, a portfolio is a ready-made container (e.g., a box, a folder, a bag or briefcase) that contains different types of printed work (posters, brochures, photographs, catalogues, etc.) (Pibernik, Dolic, \& Kanizaj, 2014). Educationally, a portfolio refers to a collection of evidence that reflects a student's achievements, competencies (Williams \& Walker, 2018), and progress over time (Challis, 2005).

Due to storage and access problems educators have shifted to electronic portfolios where students' work could be stored on floppy disk, hard disk, and CD-ROM (Chang \& Tseng, 2009). Later, digital media and Web 2.0 technologies have markedly contributed to portfolios (Easton \& Easton, 2011) by shifting them to web-based model (Chang \& Wu, 2012) where all kinds of electronic materials can be kept, where different technologies are used (websites, word processing programs, social networking applications, etc.), and where students, instructors, advisors and principals can work in a harmony (Aktay \& Gultekin, 2013). This model is the Webfolio, which can alternatively be called web-based portfolio (Chang \& Wu, 2012), online portfolio (Shaltry, Henriksen, Wu, \& Dickson, 2013), internet-based portfolio (Hung, 2006), netfolio (Barbera, 2009), and virtual portfolio (Sorensen, Tolsby, \& Dirckinck-Holmfeld, 2002).

A webfolio can be defined as a web-based or online version of a paper portfolio that can include a collection of digital artifacts (Love, McKean, \& Gathercoal, 2009) which present evidence of learners' experiences and achievements (Kim, $\mathrm{Ng} \& \mathrm{Lim}, 2010$ ). It can range from a simple web page to a sophisticated program (Mills \& Ringler, 2009) using a variety of operating systems and free online tools (Nicholson, 2018). Webfolios can find support in three theoretical foundations: constructivism - providing learners the opportunity to create meaning employing the learning style that is most suitable to them (Roeder, 2007); learner-centered instruction —allowing learners to become active participants in the learning process as they determine their learning goals, engage in reflective learning, and become responsible for their learning (Sweat-Guy \& Buzzetto-More, 2007); and the multiple intelligences theory - allowing students to include text, pictures, audios, and videos (Slavin, 2017).

Webfolios have the potential to serve such diverse purposes (Gibson \& Barrett, 2003) as the storage of (Younes, 2004), presentation of (Dorn, Madeja, \& Sabol, 2003), and reflection on students' learning progress (Chang, Tseng, $\&$ Liang, 2014). They can also work as a medium of interaction, communication, and collaboration (Fiedler \& Pick, 2004) between teacher and students and also between students and students which may result in the establishment of a learning community where the members of a group can cooperate towards a common goal with the help of an instructor (Kan, 2011). Additionally, they can become archives for future generations of students to build on (Gathercoal, Love, Bryde, \& McKean, 2002).

Educators are enamored by the promise of webfolios (Easton \& Easton, 2011) as they can offer many advantages over their traditional paper-based counterparts. These advantages include:the use of multimedia (Barrett, 2006b), elimination of physical storage problems (Meyer \& Latham, 2008), duplicability (Heath, 2005), flexibility (Williams \& Walker, 2018), portability (Simatele, 2015), ease of access (Juhana et al., 2018) to a variety of reviewers (Taggart \& Wilson, 2005), low cost (Lynch \& Purnawarman, 2004), transportation (Aktay \& Gultekin, 2013), organized content (Juhana et al., 2018), personalization, and creativity (Nicholson, 2018). Moreover, 
webfolios are easily and quickly modified (Simatele, 2015), more environmentally friendly (Nicholson, 2018), viewed by multiple users synchronously (Nicholson, 2018), and available through email and the web (Clazie 2010).

Moreover, webfolios offer more advantages for both teachers and students. As for teachers, webfolios help them plan and manage instruction (Sherman, 2006), offer them a variety of ways to motivate all types of students (Tuksinvarajarn \& Todd, 2009), allow them to access and view a student's work on multiple occasions before submission (Nicholson, 2018), enhance their technological skills (Ledoux \& McHenry, 2006; Wall, Higgins, Miller, \& Packard, 2006), and support their professional development and career progression (Love et al., 2009).

As for students, webfolios provide a personalized space to bring together both formal and informal learning experiences (Kan, 2011), facilitate student-centered teaching (Avraamidou \& Zembal-Saul, 2006), foster peer assessment (Stevenson, 2006), support lifelong learning (Fournier, Lane, \& Corbett, 2007; Rathburn, 2007), enhance collaboration (Greenberg, 2004; Hastie \& Sinelnikov, 2007) and, provide advisement and career planning (Lorenzo \& Ittelson, 2005). Moreover, they help students demonstrate their skills (Guo \& Greer, 2006) and be available on the global job market (Pibernik et al., 2014).

In order to be successfully implementing webfolios, teachers are required to: define the aim of the webfolios (Ali, 2005), clearly define their criteria and expectations of the webfolios, provide students with extensive support (Ramey \& Hay, 2003), review students' work, provide feedback (Barrett, 2006a), encourage reflective practice, and evaluate the webfolios (Ali, 2005). There are general steps for implementing webfolios. The first step is collecting where students collect and save their learning products that show their achievement and experience (Barrett, 2000). These products can be text, pictures, graphics, audio or video recordings (Heath, 2005). The second step is selecting where students evaluate the learning products they already saved in order to identify those that show achievement of specific standards (Barrett, 2000). The next step is reflecting where students reflect on both their work and the criteria for selecting certain artifacts to be included in their webfolios. The following step is organizing where students make use of the technological advantages of the web in order to make easy and visually appealing connections between various learning products (Gibson \& Barrett, 2003). The final step is presenting where the webfolios are presented including students' learning products.

Some educators found a positive effect for traditional portfolios (Kicken, Brand-Gruwel, \& Van Merrienboer, 2008; Murad \& Varkey, 2008; Thrush, O'Sullivan, Putten, \& Kamin, 2005; Van Schaik, Plant, \& O'sullivan, 2013) as well as webfolios (Abrami, Venkatesh, Meyer, \& Wade, 2013; Beckers, Dolmans, \& Merriënboer, 2016; Fung et al., 2000; Kicken, Brand-Gruwel, van Merriënboer, \& Slot, 2009; Meyer, Abrami, Wade, Aslan, \& Deault, 2010; Ziegler \& Moeller, 2012) on students' SDL.

\section{Method}

\subsection{Design and Sample}

A single-group pre-posttest research design was used. Participants of the study were 52 EFL students enrolled at the Sociolinguistics course. They were all pretested in SDL readiness before the treatment and then posttested after it.

\subsection{Instrument}

Guglielmino's (1977) SDL Readiness Scale (SDLRS) was used in the present study. It is a self-reporting questionnaire designed to determine how ready students are to engage in learning activities on their own. SDLRS measures eight dimensions: love of learning; self-concept as an effective, independent learner; tolerance of risk, ambiguity, and complexity in learning; creativity; view of learning as a lifelong, beneficial process; initiative in learning; self-understanding; and acceptance of responsibility for one's own learning. SDLRS includes 58 Likert-type items with 5 response choices: (5) almost always true of me, (4) usually true of me, (3) sometimes true of me, (2) not often true of me, and (1) almost never true of me. The scores resulting from the questionnaire range between a minimum of 58 to a maximum of 290. Content validity of SDLRS was confirmed by three TEFL specialists while its internal reliability was estimated by Wiley (1983) to be 0.91 .

\subsection{Procedures}

Procedures of the current study were carried out in the College of Sciences and Humanities-Jubail, Imam Abdulrahman Bin Faisal University during the 2018/2019 academic year. Those procedures were executed in four stages: 1) planning, 2) pretesting, 3) implementing webfolios, and 4) posttesting. In the planning stage, participants attended a 90-minute orientation session where they learned the concept of webfolios, their benefits, and how to create them. Then, they used their Blackboard accounts to create their webfolios under the supervision of the researchers. In the following stage, participants were pretested in SDL readiness using the SDLRS. 
The third stage, implementing webfolios, consisted of five steps: goal setting, collecting, selecting, reflecting, and presenting. First, participants set the goals of their webfolios with the help of the researchers to make sure that they were aligned with the learning outcomes of the Sociolinguistics course. Then, they started collecting their work which included all types of artifacts: text, pictures, audio recordings, video clips, and hyperlinks to external web sites. During the selecting step, participants chose the artifacts that would be included in their webfolios in light of the goals they had set before. The next step was reflecting where each participant wrote her reflection not only on each artifact she selected but also about her webfolio as a whole. Finally, participants presented their webfolios during a live broadcast through the Blackboard discussion feature. After the treatment, all participants were posttested in SDL readiness using the SDLRS.

\section{Results}

Paired-samples t-test showed a statistically significant difference between the means of scores of the participants between the pretest and the posttestof SDL readiness in favor of the posttest $(t=7.14, p<0.05)$. See the Table below.

Table 1. Difference between the means of scores of the participants between the pretest and posttest of SDL readiness

\begin{tabular}{|c|c|c|c|c|c|c|}
\hline & \multicolumn{3}{|c|}{ Paired Differences } & $\mathrm{t}$ & $\mathrm{df}$ & Sig. (2-tailed) \\
\hline Posttest-Pretest & $\begin{array}{l}\text { Mean } \\
29.33\end{array}$ & $\begin{array}{c}\text { Std. Deviation } \\
29.63\end{array}$ & $\begin{array}{c}\text { Std. Error Mean } \\
4.11\end{array}$ & 7.14 & 51 & 0.00 \\
\hline
\end{tabular}

\section{Discussion}

The hypothesis of the present study stated that a statistically significant difference (at 0.05 level of significance) would exist between the pretest and posttest of participants' SDL readiness scores in favor of the posttest. Paired-samples t-test was used and it showed a statistically significant difference in favor of the posttest $(\mathrm{t}=7.14$, $\mathrm{p}<0.05)$. Therefore, it can be concluded that using webfolios improved Saudi EFL students' SDL readiness. This result is supported by the results reached by Abrami et al. (2013), Beckers et al. (2016), Kicken et al. (2009), Meyer et al. (2010), and Ziegler and Moeller (2012) who found a positive effect for webfolios on students' SDL. This result is also confirmed by Fung et al.'s (2000) belief that learners can assume ownership and control of their webfolios as well as Kicken et al.'s (2008) confirmation that webfolios have built-in features that can improve learners' self-directed learning.

Moreover, the result of the present study finds support in prior a considerable body of literature indicating that using information and communication technologies can play important roles in improving SDL (e.g., Ceylaner \& Karakus, 2018; Dawson, Macfadyen, Evan, Foulsham, \& Kingstone, 2012; Rampai, 2015; Yuen, Koo, \& Woods, 2018). Therefore, the technological component of the webfolio may act as one explanation for the reached result.

Another body of literature supports the result of the present study from the perspective that webfolios possess some characteristics that help to improve SDL. The first of these characteristics is the ease of access for the participants as they could easily log into their webfolios through their Blackboard accounts on their laptops or cell phones at any time and any place. Moreover, using webfolios did not demand any technical capability on the part of the participants as they were accustomed to the use of Blackboard as their learning management system. Therefore, it allowed each participant to independently create her webfolio, complete the learning tasks, collect and select the items to be included in the webfolio, and finally present them. This was confirmed by the findings of some previous research studies that found positive impact of using blackboard on SDL (Green et al., 2006; Hamlett, 2006).

Another larger body of literature supports the result of the present study in light of the steps of webfolios. For example, the first step of creating webfolios was engaging students in a goal setting process where they were responsible for setting some goals for their webfolios. This might have improved their SDL as found by some studies (e.g., Emery et al., 2014; Hematian, Rezaei, \& Mohammadyfar, 2016). Moreover, participants were required to collect their products throughout the course and later to select specific artifacts based on specific criteria. This might have promoted students' responsibility over their learning (Beckers et al., 2018). Each participant was also directed to organize and present her webfolio in the way that suited her and showed her personality. This might have helped them become self-directed learners as pointed out by Jossberger, Brand-Gruwel, Boshuizen, and Wiel (2010) that the learner who is self-directed is the learner that can arrange, execute, and fulfill learning independently. 
Another step in the webfolio process that may have helped to improve participants' SDL is that they were required to self- as well as peer-assess their webfolios. This is confirmed by the results of some studies that found that self (e.g., Yu, 2013b; Mahmoodi-Shahrebabaki, 2014) as well as peer assessment (Sivan, 2000; Ballantyne, Hughes, \& Mylonas, 2002; Papinczak, Young, \& Groves, 2007; Yu, 2013a) improve SDL. Moreover, during the webfolio process, participants were required to reflect on both individual artifacts and on their webfolios as a whole. This action might have played a role in enhancing SDL because as Robertson (2011) assures, reflection is an essential aspect of SDL. This explanation finds support in Embo, Driessen, Valcke, and van der Vleuten's (2014) as well as King's (2011) studies where they found that reflection improves SDL.

A final explanation for the result of the present study is the coaching and feedback participants received from the teacher throughout the webfolio creation process. Moreover, the comments were given to students privately as there was an option in Blackboard that gave choice to the participant whether to make comments hidden from users who can view the portfolio. This could have helped the participants to feel free in receiving the researchers' comments without being embarrassed. As Zimmerman and Tsikalas (2005) put it, the development of SDL by its nature requires social interaction with more able partners. Beckers et al. (2018) add that teacher coaching is essential to support SDL.

\section{Conclusion, Recommendations, and Suggestions for Further Research}

Based on the result of the present study, it was concluded that webfolios should be used at college level to enhance students' self-directed learning readiness. The researchers recommend that: 1) EFL instructors need to enhance their students' self-directed learning readiness, 2) webfolios can be effectively used in the EFL classroom, and 3) Web-based applications should be used in teaching English as a foreign language. The researchers also suggested carrying out research studies to investigate: 1) the effect of webfolios on EFL students' reading and writing skills, 2) webfolios vs. traditional portfolios for improving EFL students' self-directed learning readiness, and 3) the effect of webfolios on EFL students' attitudes toward using web technology in their learning.

\section{References}

Abdullah, M. (2001). Self-directed learning. Retrieved from ERIC database.

Abrami, P., Venkatesh, V., Meyer, E., \& Wade, C. (2013). Using electronic portfolios to foster literacy \& self-regulated learning skills in elementary students. Journal of Educational Psychology, 105(4), 1188-1209. https://doi.org/10.1037/a0032448

Aktay, S., \& Gultekin, M. (2013). Webfolio application in primary education: Qualities \& usability of webfolio system. Turkish Online Journal of Distance Education, 14(3), 104-119.

Ali, S. (2005). An introduction to electronic portfolios in the language classroom. The Internet TESL Journal, 11(8). Retrieved November 13, 2018, from http://iteslj.org/Techniques/Ali-Portfolios.html

Ambrose, S., Bridges, M., DiPietro, M., Lovett, M., \& Norman, M. (2010). How learning works: Seven research-based principles for smart teaching. San Francisco: Jossey-Bass.

Avraamidou, L., \& Zembal-Saul, C. (2006). Exploring the influence of web-based portfolio development on learning to teach elementary science. AACE Journal, 14(2), 178-205.

Ballantyne, R., Hughes, K., \& Mylonas, A. (2002). Developing procedures for implementing peer assessment in large classes using an action research process. Assessment \& Evaluation in Higher Education, 27(5), 427-441. https://doi.org/10.1080/0260293022000009302

Barbera, E. (2009). Mutual feedback in e-portfolio assessment: An approach to the netfolio system. British Journal of Educational Technology, 40(2), 342-357. https://doi.org/10.1111/j.1467-8535.2007.00803.x

Barrett, H. (2000). Electronic teaching portfolios: Multimedia skills+portfolio development=powerful professional development. Retrieved from ERIC database.

Barrett, H. (2006a). Authentic assessment with electronic portfolios using common software \& Web 2.0 tools. Retrieved from http://helenbarrett.com/web20.html

Barrett, H. (2006b). Using electronic portfolios for classroom assessment. Connected Newsletter, 13(2), 46.

Bastable, S. (2008). Nurse as educator: Principles of teaching \& learning for nursing practice (3rd ed.). Boston: Jones \& Barlett Learning.

Beckers, J., Dolmans, D., \& Merriënboer, J. (2016). Student, Direct Thyself! Developing Self-Directed Learning Skills with an Electronic Development Portfolio. Manuscript submitted for publication. Retrieved from https://www.researchgate.net/publication/326788456_Walking_the_tightrope_with_an_e-portfolio_imbalan 
ce_between_support_and_autonomy_hampers_self-directed_learning

Beckers, J., Dolmans, D., Knapen, M., \& Merriënboer, J. (2018). Walking the tightrope with an e-portfolio: Imbalance between support and autonomy hampers self-directed learning. Journal of Vocational Education \& Training. https://doi.org/10.1080/13636820.2018.1481448

Ceylaner, S., \& Karakus, F. (2018). Effects of the flipped classroom model on students' self-directed learning readiness and attitudes towards the English course. English Language Teaching, 11(9), 129-143.

Challis, D. (2005). Towards the mature e-portfolio: Some implications for higher education. Canadian Journal of Learning \& Technology, 31(3), 49-58. https://doi.org/10.21432/T2MS41

Chang, C., \& Tseng, K. (2009). Using a web-based portfolio assessment system to elevate project-based learning performances. Interactive Learning Environments, 16(2), 25-37.

Chang, C., \& Wu, B. (2012). Is teacher assessment reliable or valid for high school students under a web-based portfolio environment? Educational Technology \& Society, 15(4), 265-278.

Chang, C., Tseng, K., \& Liang, C. (2014). Is reflection performance correlated to the learning effect in a web-based portfolio assessment environment for middle school students? Asia-Pacific Educational Research, 23(1), 73-82. https://doi.org/10.1007/s40299-013-0087-8

Chen, P., Lambert, A., \& Guidry, K. (2010). Engaging online learners: The impact of web-based learning technology on college student engagement. Computers \& Education, 54(4), 1222-1232.

Cheng, S., Kuo, C., Lin, K., \& Lee-Hsieh, J. (2010). Development \& preliminary testing of a self-rating instrument to measure self-directed learning ability of nursing students. International Journal of Nursing Studies, 47(9), 1152-1158. https://doi.org/10.1016/j.jinurstu.2010.02.002

Clazie, I. (2010). Creating your digital design portfolio: The essential guide to showcasing your design work online. Mies: RotoVision.

Cook, D., Garside, S., Levinson, A., Dupras, D., \& Montori, V. (2010). What do we mean by web-based learning? A systematic review of the variability of interventions. Medical Education, 44(8), 765-774. https://doi.org/10.1111/j.1365-2923.2010.03723.x

Dawson, S., Macfadyen, L., Evan, R., Foulsham, T., \& Kingstone, A. (2012). Using technology to encourage self-directed learning: The collaborative lecture annotation system. ASCILITE 2012: Future Challenges, Sustainable Futures, 25-28, Wellington, New Zealand.

Dorn, C., Madeja, S., \& Sabol, F. (2003). Assessing expressive learning: A practical guide for teacher directed authentic assessment in K-12 visual arts education. New Jersey: Lawrence Erlbaum.

Easton, A., \& Easton, G. (2011). Subscribing to webfolios: A scalable approach to showcasing student achievement. International Journal of Arts \& Sciences, 4(21), 223-229.

El-Gilany, A., \& Abusaad, F. (2013). Self-directed learning readiness \& learning styles among Saudi undergraduate nursing students. Nurse Education Today, 33(9), 1040-1044. https://doi.org/10.1016/j.nedt.2012.05.003

Embo, M., Driessen, E., Valcke, M., \& van der Vleuten, C. (2014). A framework to facilitate self-directed learning, assessment \& supervision in midwifery practice: A qualitative study of supervisors' perceptions. Nurse Education in Practice, 14(4), 441-446. https://doi.org/10.1016/j.nepr.2014.01.015

Emery, M., Bush, C., Bounds, R., Gillett, B., Santen, S., \& Aghera, A. (2014). 328 enhancing learning with simulation: Setting "SMART" learning goals during debriefing improves self-directed learning. Annals of Emergency Medicine, 64(4), S116-S116. https://doi.org/10.1016/j.annemergmed.2014.07.356

Fiedler, R., \& Pick, D. (2004). Adopting an electronic portfolio system: Key considerations for decision makers. Retrieved from ERIC database.

Fisher, M., \& King, J. (2010). The self-directed learning readiness scale for nursing education revisited: A confirmatory factor analysis. Nurse Education Today, 30(1), 44-48. https://doi.org/10.1016/j.nedt.2009.05.020

Fournier, J., Lane, C., \& Corbett, S. (2007). The journey to best practices: Results of a two-year study of eportfolio implementation in beginning composition courses. In C. Montgomerie, \& J. Seale (Eds.), Proceedings of World Conference on Educational Multimedia, Hypermedia \& Telecommunications 2007 (pp. 2008-2016). Chesapeake, VA: AACE. 
Francom, G. (2011). Involve me \& I learn: Providing substantial learning choices in higher education. Paper presented at the American Educational Research Association Annual Meeting, April 8-12, 2011, New Orleans, Louisiana.

Fung, M., Walker, M., Fung, K., Temple, L., Lajoie, F., Bellemare, G., \& Bryson, S. (2000). An internet-based learning portfolio in resident education: The KOALA ${ }^{\mathrm{TM}}$ multicenter program. Medical Education, 34(6), 474-479. https://doi.org/10.1046/j.1365-2923.2000.00571.x

Gathercoal, P., Love, D., Bryde, B., \& McKean, G. (2002). On implementing web-based electronic portfolios. Educause Quarterly, 2, 29-37.

Gibson, D., \& Barrett, H. (2003). Directions in electronic portfolio development. Contemporary Issues in Technology \& Teacher Education, 2(4), 559-576.

Government of Saudi Arabia. (2016). Saudi Arabia's vision for 2030. Retrieved from http://vision2030.gov.sa/en

Green, S., Weaver, M., Voegeli, D., Fitzsimmons, D., Knowles, J., Harrison, M., \& Shephard, K. (2006). The development \& evaluation of the use of a virtual learning environment (Blackboard 5) to support the learning of pre-qualifying nursing students undertaking a human anatomy \& physiology module. Nurse Education Today, 26(5), 388-395. https://doi.org/10.1016/j.nedt.2005.11.008

Greenberg, G. (2004). The digital convergence: Extending the portfolio model. Educause Review, 39(4), 28-36.

Guglielmino, L. (1977). Development of the self-directed learning readiness scale (Doctoral dissertation, University of Georgia). Retrieved from ProQuest Dissertations \& Theses.

Guglielmino, L. (2013). The case for promoting self-directed learning in formal educational institutions. SA-eDUC Journal, 10(2), 1-18.

Guo, Z., \& Greer, J. (2006). Electronic portfolios as a means for initializing learner models for adaptive tutorials. Lecture Notes in Computer Science, 4227, 482-487. https://doi.org/10.1007/11876663_40

Gureckis, T., \& Markant, D. (2012). Self-directed learning: A cognitive \& computational perspective. Perspectives on Psychological Science, 7(5), 464-481. https://doi.org/10.1177/1745691612454304

Hamlett, C. (2006). Self-directed learning and achievement in a blackboard-based college Algebra course (Unpublished doctoral dissertation). Walden University.

Hastie, P., \& Sinelnikov, O. (2007). The use of web-based portfolios in college physical education activity courses. Physical Educator, 64(1), 21-28.

Heath, M. (2005). Are you ready to go digital? The pros \& cons of electronic portfolio development. Library Media Connection, 23(7), 66-70.

Hematian, F., Rezaei, A., \& Mohammadyfar, M. (2016). On the effect of goal setting on self-directed learning, achievement motivation, \& academic achievement among students. Modern Applied Science, 11(1), 37. https://doi.org/10.5539/mas.v11n1p37

Hiemstra, R. (2013). Self-directed learning: Why do most instructors still do it wrong? International Journal of Self-Directed Learning, 10(1), 23-34.

Hung, S. (2006). Alternative EFL assessment: Integrating electronic portfolios into the classroom (Unpublished doctoral dissertation). Indiana University, Bloomington.

Jossberger, H., Brand-Gruwel, S., Boshuizen, H., \& Wiel, M. (2010). The challenge of self-directed and self-regulated learning in vocational education: A theoretical analysis and synthesis of requirements. $\begin{array}{lllll}\text { Journal of Vocational Education \& } & \text { Training, }\end{array}$ https://doi.org/10.1080/13636820.2010.523479

Juhana, A., Abdullah, A., Somantri, M., Aryadi, S., Zakaria, D., Amelia, N., \& Arasid, W. (2018, February). E-portfolio web-based for students' internship program activities. Materials Science \& Engineering, 306(1), 12003. https://doi.org/10.1088/1757-899X/306/1/012003

Kan, S. (2011). Cooperative learning environment with the Web 2.0 tool e-portfolios. Turkish Online Journal of Distance Education, 12(3), 201-214.

Kennedy, G., Judd, T., Churchward, A., Gray, K., \& Krause, K. (2008). First year students' experiences with technology: Are they really digital natives? Australasian Journal of Educational Technology, 24(1), 108-122. https://doi.org/10.14742/ajet.1233 
Kicken, W., Brand-Gruwel, S., \& Van Merrienboer, J. (2008). Scaffolding advice on task selection: A safe path toward self-directed learning in on-demand education. Journal of Vocational Education \& Training, 60, 223-239. https://doi.org/10.1080/13636820802305561

Kicken, W., Brand-Gruwel, S., van Merriënboer, J., \& Slot, W. (2009). Design \& evaluation of a development portfolio: How to improve students' self-directed learning skills. Instructional Science, 37(5), 453-473. https://doi.org/10.1007/s11251-008-9058-5

Kim, P., Ng, C., \& Lim, G. (2010). When cloud computing meets with Semantic Web: A new design for e-portfolio systems in the social media era. British Journal of Educational Technology, 41(6), 1018-1028. https://doi.org/10.1111/j.1467-8535.2010.01055.x

King, C. (2011). Fostering self-directed learning through guided tasks and learner reflection. Studies in Self-Access Learning Journal, 2(4), 257-267.

Ledoux, M. \& McHenry, N. (2006). Electronic portfolio adoption for teacher education candidates. Early Childhood Education Journal, 34(2), 103-116. https://doi.org/10.1007/s10643-006-0111-1

Lorenzo, G., \& Ittelson, J. (2005). An overview of e-portfolios. Educause Learning Initiative, 1(1), 1-27.

Love, D., McKean, G., \& Gathercoal, P. (2009). Student webfolios \& authentic assessment in information systems. Proceedings of the 2009 International SIGED: IAIM Conference.

Loyens, S., Magda, J., \& Rikers, R. (2008). Self-directed learning in problem-based learning \& its relationships with self-regulated learning. Educational Psychology Review, 20(4), 411-427. https://doi.org/10.1007/s10648-008-9082-7

Lynch, L., \& Purnawarman, P. (2004). Electronic portfolio assessments in U.S. educational \& instructional technology programs: Are they supporting teacher education? TechTrends, 48(1), 50-56. https://doi.org/10.1007/BF02784865

Mahmoodi-Shahrebabaki, M. (2014). Using self-assessment checklists to make English language learners self-directed. International Journal for Research in Education, 3(6), 9-20.

Merriam, S., Caffarella, R., \& Baumgartner, L. (2007). Learning in adulthood: A comprehensive guide (3rd ed.). San Francisco: Jossey-Bass.

Meyer, B., \& Latham, N. (2008). Implementing electronic portfolios: Benefits, challenges, \& suggestions. Educause Quarterly, 31(1), 34-41.

Meyer, E., Abrami, P., Wade, C., Aslan, O., \& Deault, L. (2010). Improving literacy \& metacognition with electronic portfolios: Teaching \& learning with ePEARL. Computers \& Education, 55(1), 84-91. https://doi.org/10.1016/j.compedu.2009.12.005

Mills, L., \& Ringler, (2009). Implementing webfolios in principal preparation internships: Pluses \& pitfalls. International Journal of Educational Leadership Preparation, 4(4), 1-9.

Murad, M., \& Varkey, P. (2008). Self-directed learning in health professions education. Annals Academy of Medicine Singapore, 37(7), 580.

Nicholson, D. (2018). Enhancing student engagement through online portfolio assessment. Practitioner Research in Higher Education, 11(1), 15-31.

O'Shea, E. (2003). Self-directed learning in nurse education: A review of the literature. Journal of Advanced Nursing, 43(1), 62-70.

Papinczak, T., Young, L., \& Groves, M. (2007). Peer assessment in problem-based learning: A qualitative study. Advances in Health Sciences Education, 12(2), 169-186. https://doi.org/10.1007/s10459-005-5046-6

Payne, S., Rundquist, P., Harper, W., \& Gahimer, J. (2013). Self-directed learning readiness \& self-determination for selected rehabilitation professional students: The impact of clinical education. International Journal of Self-Directed Learning, 10(1), 35-45.

Pibernik, J., Dolic, J., \& Kanizaj, B. (2014). What is creativity in web portfolio design? Digital Creativity, 25(2), 126-139. https://doi.org/10.1080/14626268.2013.811425

Ramey, S., \& Hay, M. (2003). Using electronic portfolios to measure student achievement \& assess curricular integrity. Nurse Educator, 28(1), 31-36. https://doi.org/10.1097/00006223-200301000-00012

Rampai, N. (2015). Model of knowledge management via social media to enhance graduated Student's 
self-directed learning skill. International Journal of Information and Education Technology, 5(10), 799-802. https://doi.org/10.7763/IJIET.2015.V5.614

Rathburn, J. (2007). Using electronic portfolios to document \& assess student learning: Implications for business education \& accreditation. Paper presented at AACSB Faculty Conference on Learning, Orlando, Fl, June 5-9, 2007.

Robertson, J. (2011). The educational affordances of blogs for self-directed learning. Computers \& Education, 57(2), 1628-1644. https://doi.org/10.1016/j.compedu.2011.03.003

Roeder, J. (2007). The use of student portfolios to teach the bill of rights. Retrieved from http://ted.coe.wayne.edu/sse/finding/Roeder.doc

Saxena, S. (2013). How technology supports self-directed learning. Retrieved from http://edtechreview.in/news/824-howtechnology-supports-self-directed-learning

Shaltry, C., Henriksen, D., Wu, M., \& Dickson, W. (2013). Teaching pre-service teachers to integrate technology: Situated learning with online portfolios, classroom websites, \& Facebook. TechTrends, 57(3), 20-25. https://doi.org/10.1007/s11528-013-0658-9

Sherman, G. (2006). Instructional roles of electronic portfolios. In A. Jafaria, \& C. Kaufman (Eds.), Handbook of research on eportfolios (pp. 1-14). Hershey, PA: Idea Group Reference. https://doi.org/10.4018/978-1-59140-890-1.ch001

Silva, J. (2009). Extensive reading through the Internet: Is it worth the while? International Journal of English Studies, 9(2), 81-96.

Simatele, M. (2015). Enhancing the portability of employability skills using e-portfolios. Journal of Further \& Higher Education, 39(6), 862-874. https://doi.org/10.1080/0309877X.2014.953461

Sivan, A. (2000). The implementation of peer assessment: An action research approach. Assessment in Education: Principles, Policy \& Practice, 7(2), 193-213. https://doi.org/10.1080/713613328

Slavin, R. (2017). Educational psychology: Theory \& practice. Delhi: Pearson Education.

Sorensen, E., Tolsby, H., \& Dirckinck-Holmfeld, L. (2002). Virtual portfolios for collaboration in distributed web-based learning. Retrieved from ERIC database.

Stevenson, H. (2006). Using ePortfolios to foster peer assessment, critical thinking \& collaboration. In A. Jafaria, \& C. Kaufman (Eds.), Handbook of research on eportfolios (pp. 112-124). Hershey, PA: Idea Group Reference. https://doi.org/10.4018/978-1-59140-890-1.ch012

Sweat-Guy, R., \& Buzzetto-More, N. (2007). A comparative analysis of common e-portfolio features \& available platforms. Issues in Informing Science \& Information Technology, 4, 327-342. https://doi.org/10.28945/3108

Taggart, G., \& Wilson, A. (2005). Promoting reflective thinking in teachers: 50 action strategies (2nd ed.). CA: Corwin Press.

Thrush, C., O'Sullivan, P., Putten, J., \& Kamin, C. (2005). Portfolio assessment \& self-directed learning. Academic Exchange Quarterly, 9, 240-244.

Tuksinvarajarn, A., \& Todd, R. (2009). The e-pet: Enhancing motivation in e-portfolios. Forum, 1, 22-31. https://doi.org/10.1016/S0840-4704(10)60287-6

Van Schaik, S., Plant, J., \& O'sullivan, P. (2013). Promoting self-directed learning through portfolios in undergraduate medical education: The mentors' perspective. Medical teacher, 35(2), 139-144. https://doi.org/10.3109/0142159X.2012.733832

Wall, K., Higgins, S., Miller, J., \& Packard, N. (2006). Developing digital portfolios: Investigating how digital portfolios can facilitate pupil talk about learning. Technology, Pedagogy \& Education, 15(3), 261-273. https://doi.org/10.1080/14759390600923535

Wiley, K. (1983). Effects of a self-directed learning project \& preference for structure on self-directed learning readiness. Nursing Research, 32, 181-185. https://doi.org/10.1097/00006199-198305000-00011

Williams, J., \& Walker, L. (2018). From paper to online-the electronic practice webfolio: A reflective account. British Journal of Midwifery, 26(8), 540-544. https://doi.org/10.12968/bjom.2018.26.8.540

Younes, M. (2004). Web-based student portfolio system at AAWC. Paper presented at the 2004 HCT Annual 
Conference Workshops, Dubai, UAE.

Yu, G. (2013a). The case of St Margaret's Girls' College: How SLOA promotes self-assessment \& peer assessment to enhance secondary school student English learning. In M. Mok (Ed.), Self-directed learning-oriented assessments in the Asia-Pacific (pp. 393-411). Dordrecht, the Netherlands: Springer. https://doi.org/10.1007/978-94-007-4507-0_20

$\mathrm{Yu}, \mathrm{T}$. (2013b). The use of self-assessment to facilitate self-directed learning in mathematics by Hong Kong secondary school students (Unpublished doctoral dissertation). Durham University.

Yuen, M., Koo, A., \& Woods, P. (2018). Online video for self-directed learning in digital animation. Turkish Online Journal of Educational Technology, 17(3), 91-103.

Ziegler, N., \& Moeller, A. (2012). Increasing self-regulated learning through the linguafolio. Foreign Language Annals, 45(3), 330-348. https://doi.org/10.1111/j.1944-9720.2012.01205.x

Zimmerman, B., \& Tsikalas, K. (2005). Can computer-based learning environments (CBLEs) be used as self-regulatory tools to enhance learning? Educational Psychologist, 40(4), 267-271. https://doi.org/10.1207/s15326985ep4004_8

\section{Copyrights}

Copyright for this article is retained by the author(s), with first publication rights granted to the journal.

This is an open-access article distributed under the terms and conditions of the Creative Commons Attribution license (http://creativecommons.org/licenses/by/4.0/). 